\title{
WILD EDIBLE FRUITS OF PALPA DISTRICT, WEST NEPAL
}

\author{
RAS BIHARI MAHATO \\ Department of Botany, R. R. Multiple campus \\ Janakpur, Nepal \\ rasbihari_mahato@yahoo.com
}

\section{ABSTRACT}

This paper documents the wild edible fruits of tropical and subtropical forest of Palpa District, West Nepal. Thirty-seven plant species under 17 families and 27 genera were identified as wild edible fruit. Over $86 \%$ percent of them were trees and shrubs (32 species), $11 \%$ herbs (4 species) and the remaining 3\% (1 species) woody climbers. Moraceae (9 species), Rosaceae (7 species), Anacardiaceae, Berberidaceae, Combretaceae, Fabaceae, Solanaceae and Rutaceae ( 2 species each) were the most common families constituting about $75.7 \%$ of edible plants. The remaining 24.3\% (9 species) of edible plants were distributed among 9 families and 9 genera. A considerable number of wild fruits are sold in market. These are Aegle marmelos, Artocarpus integra, Artocarpus lakoocha, Choerospondias axillaris, Myrica esculenta, Phoenix humilis, Phyllanthus emblica, Prunus persica, Pyracantha crenulata,Tamarindus indica, Terminalia bellirica, Terminalia chebula, Zanthoxylum armatum and Zizyphus mauritiana. Medicinal uses of some major economically important fruits are also documented.

Keywords: tropical, subtropical forest, medicinal uses, wild fruits, sweet nuggets

\section{INTRODUCTION}

Wild edible fruits play an important role in the economy of rural people especially living in the hilly region by providing them food and also in generating side income. They collect the wild edible fruits from forest and sold in market regularly. The rural people have better knowledge of wild edible fruits as they visit the forest regularly and have constant association and dependence on these forests and its products for their livelihood. More often jams, pickles and curry are prepared from these fruits by local people (Maden,1998). According to Cotton (1997) rural people not only depend on wild plants as sources of food, medicine, fodder and fuel, but also developed methods of resource management, which may be fundamental to the conservation of some of the world's important habitats.

Manandhar (2002) describes the uses of astonishing 1517 kinds of plants belonging to 858 genera and 195 families in his book Plants and People of Nepal. It is equal to perhaps one-fifth of the entire Nepalese flora. He reported 1002 medicinal plants, 651 food plants and 696 plants are used for a rich variety of the other purposes. He also reported that many of the plants have more than one application.

The study of wild edible fruits in Nepal was carried out by Bhandary (1978), Banerji (1995), Shrestha (1983), Bajracharya (1984) and Maden (1998). 


\section{MATERIALS AND METHODS}

\section{Study area}

The study area is located in Palpa district (27034' to $27^{0} 57^{\prime} \mathrm{N}$ latitudes and $83^{\circ} 15^{\prime}$ to $84^{0} 22^{\prime} \mathrm{E}$ longitudes) (fig. 1). The topographical features of study area vary greatly from lowland of north foot of Churiya hill, inner mid-hills with terrace lowlands to high Mahabharat range. The altitude of this district varies from $300 \mathrm{~m}$ to $1900 \mathrm{~m}$. It possesses tropical to subtropical types of climate. Throughout the hill regions loams and sandy loams are the most common soil types, both on sloping lands and on alluvial terraces. The majority of the forest soils belong to the brown forest soil category (Singh \& Singh, 1992).

Palpa district enjoys a monsoon type of climate with wet summer and dry winter. Maximum percentage of rainfall occurs during the months of June to September. There is monsoon climate with hot, wet summer and mild warm dry winter up to $1000 \mathrm{~m}$; but in the Mahabharat range between 1000 and $2000 \mathrm{~m}$ there is a warm temperate monsoon climate with warm and wet summers and cool and dry winters. During summer months (May and June) the maximum temperature is recorded as $28^{\circ}$ and $32^{\circ} \mathrm{C}$, while in winter months (December and January) the minimum temperature reaches to $4^{\circ}-9^{\circ} \mathrm{C}$. Relative humidity is normally highest during rainy season (June-September), often recorded from $80-87 \%$.

\section{Study areas}

Five study areas were selected at different parts in Palpa district for the collection of plants being used as wild edible fruit on the basis of varied altitude and richness of species, which also comprised rich cultural diversity (fig.1).

(a) Jhumsa area $(350 \mathrm{~m})$ : Situated about $29 \mathrm{~km}$ south to Tansen at the foot of Churiya hill, $10 \mathrm{~km}$ north to Butwal, Rupandehi district.

(b) Styabati lake (872 m): Situated within $25 \mathrm{~km}$ south to Tansen.

(c) Prabas area $(850 \mathrm{~m}$.): Situated about $9 \mathrm{~km}$ south to Tansen, at the foot of the Shrinagar Dada.

(d) Tansen area (1150-1370 m): District headquarter and surrounding areas of Palpa district, and

(e) Shrinagar dada $(1440 \mathrm{~m})$ : Situated on the west-north of main market of Tansen within two kilometer. 

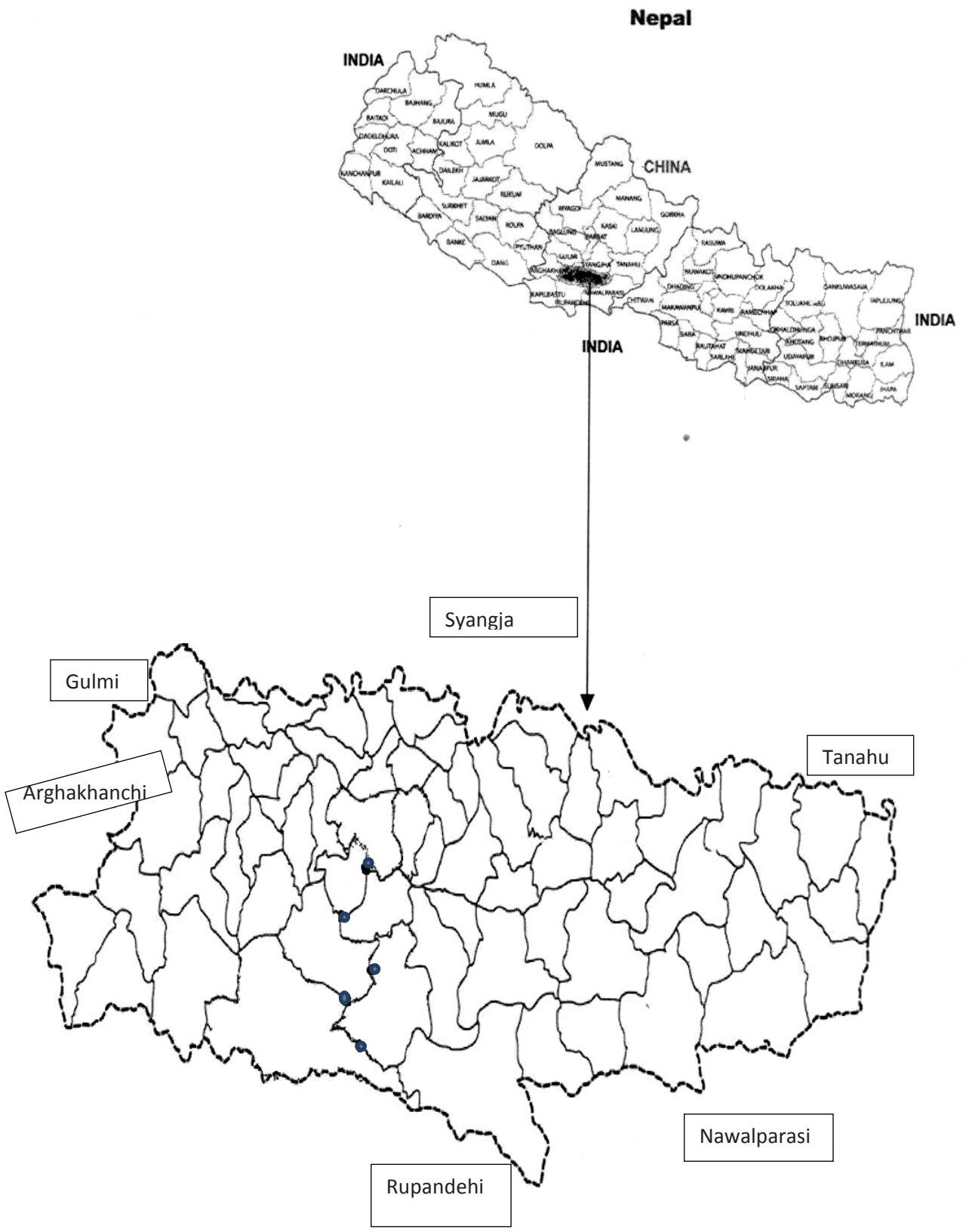

FIG.1. Map of Nepal showing Palpa district in detail. 


\section{Plant collection and identification}

Plant specimens were collected from their natural habitats in two main seasons, each lasting three to four months at intervals of 15 days. First collection were made during monsoon (June to July) and after monsoon (August to November), because most of the plant flourish during these periods. Second collection was made before monsoon (March to May, 2004 and updated in 2012).

Rural people involved in wild fruit collection and knowledgeable villagers associated with forest are consulted and interviewed to collect the information about the wild edible fruits during the field trips. Ethnomedicinal uses of some economically important plants were collected with help of local healers (Dhami, Jhankari,Guruwa and Vaidya) during the field trips and also with the help of published literature (Mahato \& Chaudhary, 2005).

The plant specimens and edible fruits were collected from the natural habitats, tagged properly and fruits were stored in plastic bags. The plants specimens were pressed, following the standard technique (Alexiades,1996; Cunningham, 2001) for voucher specimen preparation. Some of thespecimens were identified in field and those unidentified were identified at the National Herbarium and Plant Laboratories, Godawari and Central Department of Botany, Tribhuvan University, Kirtipur.The voucher specimens were deposited at Central Department of Botany, Tribhuvan University, Kirtipur.

Nomenclature of the plant species follows Hara et al. $(1978,1982)$, Hara \& Williams (1979) and Press et al. (2000). The local names were noted in the field and also consulting the literature by Shrestha (1998), Grierson \& Long (1983), Noltie (1994) were given. The plant species are arranged alphabetically followed by local name, family, growth form (GF), edible parts and fruiting season.

\section{RESULTS}

Thirty-seven plant species, distributed among 17 families and 27 genera were identified as wild edible fruits (table 1 ). Over $86 \%$ percent of them were trees and shrubs ( 32 species), $11 \%$ herbs (4 species) and the remaining 3\% (1 species) woody climbers. These are Aegle marmelos, Artocarpus integra, Artocarpus lakoocha, Bauhinia vahlii, Berberis asiatica, Cannabis sativa, Castanopsis indica, Choerospondias axillaris, Diospyros malabarica, Duchesnea indica, Ficus auriculata, Ficus benghalensis, Ficus glaberrima, Ficus racemosa, Ficus semicordata, Ficus subincisa, Fragaria nubicola, Maesa macrophylla, Mahonia napaulensis, Morus serrata, Myrica esculenta, Phyllanthus emblica, Phoenix humilis, Prunus persica, Pyracantha crenulata, Pyruspashia, Rhus javanica, Rubus ellipticus, Rubus paniculatus, Solanum nigrum, Solanum torvum, Syzygium cumini, Tamarindus indica, Terminalia bellirica, Terminalia chebula, Zanthoxylum armatum and Zizyphus mauritiana.

\section{Discussion}

Thirty-seven species of wild edible fruit were reported in Palpa district. Of them the family Moraceaewith 9 species, Rosaceae with 7 species, Anacardiaceae, Berberidaceae, Combretaceae, Fabaceae, Solanaceae and Rutaceaewith 2 species each. These were the most important families constituting about $75.7 \%$ of edible plants. The remaining $24.3 \%$ (9 species) of edible plants were distributed among 9 families and 9 genera. A considerable 
number of wild fruits are sold in market for their fruits and medicinal value. These are Aegle marmelos, Artocarpus integra, Artocarpus lakoocha, Choerospondias axillaris, Myrica esculenta, Phyllanthus emblica, Prunus persica, Pyracantha crenulata, Syzygium cumini, Tamarindus indica, Terminalia bellirica, Terminalia chebula, Zanthoxylum armatum and Zizyphus mauritiana (table 2) .

Fruits of Choerospondias axillaris (Lapsi) are widely used in pickles, jam, candy and various kinds of sweet nuggets (Titaura) preparation. Fruits of Phyllanthus emblica (Amla) are used in sweets, sauce, pickles and various kinds of sweet nuggets preparation. Similarly, fruits of Tamarindus indica (Imali) are used in jam, pickles, sauce and various types of sweet nuggets preparation. These plants (Choerospondias axillaris, Phyllanthus emblica and Tamarindus indica) are employed on commercial level to prepare various kinds of sweet nuggets with different taste.Sweet nugget is sold in local market as well as exported to other parts of the country.

Fruits of Myrica esculenta (Kaphal) have characteristic taste and sold in market on large scale by different rural people. Ripe fruits are eaten raw with salt. The walking stick prepared from mature stem of Pyracantha crenulata is sold in market. Similarly, the fruits of Zanthoxylum armatum are sold in local market by various rural people. These are used as pickles and spices. Thus, the result shows that the wild edible fruits play an important role in the economy of rural people and a large number of people are involved in selling of wild fruits to fulfill their daily needs.

Medicinal uses of some major economically important fruits are also documented. These are Aegle marmelos, Choerospondias axillaris, Myrica esculenta, Phyllanthus emblica, Tamarindus indica, Terminalia bellirica, Terminalia chebula and Zanthoxylum armatum (table 2). Among them Aegle marmelos, Phyllanthus emblica,Terminalia bellirica,Terminalia chebula and Zanthoxylum armatum are the most common medicinal plants used in different parts of the district.Fruit of Aegle marmelos is used to cure constipation and dyspepsia. One fourth of an unripe fruit is taken orally to cure diarrhoea and root juice is used to cure fever (Mahato \& Chaudhary, 2005). Dried fruit of Phyllanthus emblica is used to cure diarrhoea. Juice of fresh fruit is taken orally to cure indigestion, jaundice, anaemia and heart complaint (Mahato \& Chaudhary, 2005). Roasted fruits of Terminalia bellirica are chewed to improve sore throats. They are eaten three times a day for a week to cure cough. Roasted fruits of Terminalia chebula are chewed to improve sore throats. They are eaten three times a day for a week to cure cough. Dried fruits of Phyllanthus emblica, Terminalia bellirica, Terminalia chebula are used in the preparation oftriphalachuran (powder of three myrobalans) an Ayurvedic medicine used for liver and gastrointestinal troubles. The triphalachuran (powder of three myrobalans) is used throughout the country.

Decoction of fruit of Zanthoxylum armatum prepared in a cup of water with salt is taken warm before bedtime to relieve abdominal pain. Powder of fruit is taken orally with warm water to treat constipation, stomach disorder and toothache. These results were compared with Mahato \& Chaudhary (2005).

\section{ACKNOWLEGEMENTS}

I am thankful to the people of the Palpa district who kindly shared their indigenous knowledge 
throughout the field study. Without their participation this research would not have been possible. I am grateful to National Herbarium and Plant Laboratories, Godawari (KATH), Nepal for their cooperation in plant identification.

\section{REFERENCES}

Alexiades, M N (1996) Selected guidelines for ethnobotanical research: a field manual.The New York Botanical Garden, NY, USA.

Bajracharya, D (1984) Some edible wild fruits of Kathmandu Valley. In Majupuria, T C (ed) Nepal Nature`s Paradise. White Lotus Co. Ltd., Bangkok, Thailand.

Banerji, M L (1955) Some wild edible and medicinal plants of east Nepal. Jour. Bomb. Nat. Soc. 35:153-155.

Bhandary, H R (1978) Biochemical analysis of some edible wild fruits (at ripe and unripe stages) of Kathmandu Valley. MSc. dissertation, Central Department of Botany, Tribhuvan University, Kirtipur, Kathmandu, Nepal.

Cotton, C M (1997) Ethnobotany: principles and applications.John Wiley \& Sons, Chichester, UK.

Cunningham, A B (2001) Applied ethnobotany: people, wild plant use and conservation.Earthscan Publication Ltd. London, UK.

Grierson, A J C; Long, D G (1983) Flora of Bhutan.Vol. I- II.Royal Botanic Garden, Edinburgh and Royal Government of Bhutan.

Hara, H; Williams, L H J (1979) An enumeration of the flowering plants of Nepal. Vol. II. British Museum (Natural History) London, UK.

Hara, H; Chater, A O; Williams, L H J (1982) An enumeration of the flowering Plants of Nepal. Vol. III. British Museum (Natural History) London, UK.

Hara, H; Stearn, W T; Williams, L H J (1978) An enumeration of the flowering plants of Nepal, Vol. 1. British Museum (Natural History) London, UK.

Maden, K (1998) General survey and biochemical analysis of wild edible fruits of Koshi zone, eastern Nepal. Journal of Tribhuvan University 21(1): 77-84.

Mahato, R B; Chaudhary, R P (2005) Ethnomedicinal plants of Palpa district, Nepal.Ethnobotany 17: 152-163.

Manandhar, N P (2002) Plants and people of Nepal. Timber press Inc., USA.

Noltie, H J (1994) Flora of Bhutan.Vol.111 part 1. Royal Botanic Garden Edinburgh.

Noltie, H J (2000) Flora of Bhutan.Vol. 111 part 2. Royal Botanic Garden Edinburgh and Royal Government of Bhutan.

Press, J R; Shrestha, K K; Sutton, D A (2000) Annotated checklist of the flowering plants of Nepal. The Natural History Museum, London, UK.

Shrestha, K (1983) Wild leafy and fruity vegetable consumed by the local inhabitants of Dharan. Jour. Nat. Hist. Mus. 7: 35-42.

Shrestha, T B (1998) Plant conservation in Nepal. A country paper presented in India. Subcontinent plant specialist group meeting at Corbett National Park, India, 7-9 January 1998.

Singh, J S; Singh, S P (1992) Forest of Himalaya. Gyanodaya Prakashan Nainital, India. 
Mahato : Wild Edible Fruits of Palpa

TABLE 1. Wild edible fruits of Palpa distict.

\begin{tabular}{|c|c|c|c|c|c|c|c|}
\hline S.N. & Species & Local name & Family & GF & $\begin{array}{c}\text { Edible } \\
\text { part }\end{array}$ & $\begin{array}{l}\text { Fruiting } \\
\text { season }\end{array}$ & Elevation \\
\hline 1 & $\begin{array}{l}\text { Aegle marmelos (L.) } \\
\text { Correa }\end{array}$ & Bel & Rutaceae & $\mathrm{T}$ & Fruit & \begin{tabular}{|l|} 
April- \\
September
\end{tabular} & $870 \mathrm{~m}$ \\
\hline 2 & $\begin{array}{l}\text { Artocarpus integra } \\
\text { (Thunb.) Merr. }\end{array}$ & Kathar & Moraceae & $\mathrm{T}$ & Fruit & April-June & $350 \mathrm{~m}$ \\
\hline 3 & $\begin{array}{l}\text { Artocarpus lakoocha } \\
\text { Wall. ex Roxb. }\end{array}$ & Badahar & Moraceae & $\mathrm{T}$ & Fruit & April-June & $350 \mathrm{~m}$ \\
\hline 4 & $\begin{array}{l}\text { Bauhinia vahlii Wight } \\
\text { and Arn. }\end{array}$ & Bhoralo & Fabaceae & Wc & Seed & June-July & $850 \mathrm{~m}$ \\
\hline 5 & $\begin{array}{l}\text { Berberis asiaticaRoxb. } \\
\text { ex DC. }\end{array}$ & Chutro & Berberidaceae & $S$ & Fruit & April-May & $1300 \mathrm{~m}$ \\
\hline 6 & Cannabis sativa L. & Bhang & Cannabaceae & $\mathrm{H}$ & Seed & April-May & $350 \mathrm{~m}$ \\
\hline 7 & $\begin{array}{l}\text { Castanopsis indica } \\
\text { (Roxb.) Miq. }\end{array}$ & Dalne katus & Fagaceae & $T$ & Fruit & $\begin{array}{l}\text { November- } \\
\text { December }\end{array}$ & $1400 \mathrm{~m}$ \\
\hline 8 & $\begin{array}{l}\text { Choerospondias } \\
\text { axillaris } \\
\text { Roxb. }\end{array}$ & Lapsi & Anacardiaceae & $T$ & Fruit & \begin{tabular}{|l|} 
June- \\
October
\end{tabular} & $1200 \mathrm{~m}$ \\
\hline 9 & $\begin{array}{l}\text { Diospyros malabarica } \\
\text { (Desr.) Kostel. }\end{array}$ & Khalluk & Ebenaceae & $T$ & Fruit & \begin{tabular}{|l|} 
December- \\
February
\end{tabular} & $1200 \mathrm{~m}$ \\
\hline 10 & $\begin{array}{l}\text { Duchesnea indica } \\
\text { (Andrews) Focke } \\
\text { Sarpe }\end{array}$ & Bhui kaphal & Rosaceae & $\mathrm{H}$ & Fruit & March-June & $1300 \mathrm{~m}$ \\
\hline 11 & Ficus auriculataLour. & Nevaro & Moraceae & $T$ & Fruit & $\begin{array}{l}\text { November- } \\
\text { December }\end{array}$ & $1300 \mathrm{~m}$ \\
\hline 12 & Ficus benghalensis L. & Bar & Moraceae & $\mathrm{T}$ & Fruit & $\begin{array}{l}\text { December- } \\
\text { January }\end{array}$ & $850 \mathrm{~m}$ \\
\hline 13 & $\begin{array}{l}\text { Ficus glaberrima } \\
\text { Blume }\end{array}$ & Pakhri & Moraceae & $T$ & Fruit & \begin{tabular}{|l|} 
December- \\
January
\end{tabular} & $870 \mathrm{~m}$ \\
\hline 14 & Ficus racemosa L. & Dumari & Moraceae & $T$ & Fruit & $\begin{array}{l}\text { November- } \\
\text { December }\end{array}$ & $1100 \mathrm{~m}$ \\
\hline 15 & $\begin{array}{l}\text { Ficus semicordata } \\
\text { Buch. } \\
\text {-Ham. ex Sm. }\end{array}$ & Khanyu & Moraceae & $T$ & Fruit & $\begin{array}{l}\text { November- } \\
\text { December }\end{array}$ & $1100 \mathrm{~m}$ \\
\hline 16 & $\begin{array}{l}\text { Ficus subincisa Buch.- } \\
\text { Ham. ex Sm. }\end{array}$ & Berulo & Moraceae & $\mathrm{T}$ & Fruit & \begin{tabular}{|l} 
December- \\
January
\end{tabular} & $870 \mathrm{~m}$ \\
\hline 17 & $\begin{array}{l}\text { Fragaria nubicola } \\
\text { Lindl. ex Lacaita }\end{array}$ & Bhuiainselu & Rosaceae & $\mathrm{H}$ & Fruit & $\begin{array}{l}\text { August- } \\
\text { October }\end{array}$ & $1300 \mathrm{~m}$ \\
\hline
\end{tabular}




\begin{tabular}{|c|c|c|c|c|c|c|c|}
\hline 18 & $\begin{array}{l}\text { Maesa macrophylla } \\
\text { A. Dc. }\end{array}$ & Bhogate & Myrsinaceae & S & Fruit & June-July & $1100 \mathrm{~m}$ \\
\hline 19 & $\begin{array}{l}\text { Mahonia napaulensis } \\
\text { DC. }\end{array}$ & Jamane mandro & Berberidaceae & s & Fruit & April-May & $1300 \mathrm{~m}$ \\
\hline 20 & Morus serrata Roxb. & Kimbu & Moraceae & $T$ & Fruit & April-June & $1200 \mathrm{~m}$ \\
\hline 21 & $\begin{array}{l}\text { Myrica esculenta Ham. } \\
\text { Ex. D. Don }\end{array}$ & Kaphal & Myricaceae & $T$ & Fruit & March- April & $1400 \mathrm{~m}$ \\
\hline 22 & $\begin{array}{l}\text { Phoenix humilis Royle } \\
\text { ex Becc. \& Hook. f. }\end{array}$ & Thakal & Palmae & $T$ & Fruit & March-May & $350 \mathrm{~m}$ \\
\hline 23 & Phyllanthus emblica L. & Amla & Euphorbiaceae & $T$ & Fruit & $\begin{array}{l}\text { September- } \\
\text { November }\end{array}$ & $350 \mathrm{~m}$ \\
\hline 24 & $\begin{array}{l}\text { Prunus persica (L.) } \\
\text { Batsch }\end{array}$ & Aaru & Rosaceae & $T$ & Fruit & $\begin{array}{l}\text { July- } \\
\text { September }\end{array}$ & $1100 \mathrm{~m}$ \\
\hline 25 & $\begin{array}{l}\text { Pyracantha crenulata } \\
\text { (D. Don) M. Roem }\end{array}$ & Ghangaru & Rosaceae & S & Fruit & $\begin{array}{l}\text { July- } \\
\text { September }\end{array}$ & $1100 \mathrm{~m}$ \\
\hline 26 & $\begin{array}{l}\text { Pyrus pashia Buch.- } \\
\text { Ham. ex D. Don }\end{array}$ & Mayal & Rosaceae & $T$ & Fruit & $\begin{array}{l}\text { September- } \\
\text { October }\end{array}$ & $1400 \mathrm{~m}$ \\
\hline 27 & Rhus javanica L. & Bhaki amilo & Anacardiaceae & $T$ & Fruit & $\begin{array}{l}\text { September- } \\
\text { October }\end{array}$ & $1300 \mathrm{~m}$ \\
\hline 28 & Rubus ellipticus Sm. & Ainselu & Rosaceae & S & Fruit & March-April & $1300 \mathrm{~m}$ \\
\hline 29 & Rubus paniculatus Sm. & Kalo ainselu & Rosaceae & S & Fruit & $\begin{array}{l}\text { August- } \\
\text { October }\end{array}$ & $1400 \mathrm{~m}$ \\
\hline 30 & Solanum nigrum L. & Kamayo & Solanaceae & $\mathrm{H}$ & Fruit & $\begin{array}{l}\text { Most of the } \\
\text { year }\end{array}$ & $350 \mathrm{~m}$ \\
\hline 31 & SolanumtorvumSwartz & Bin & Solanaceae & S & Fruit & $\begin{array}{l}\text { August- } \\
\text { September }\end{array}$ & $850 \mathrm{~m}$ \\
\hline 32 & $\begin{array}{l}\text { Syzygium cumini (L.) } \\
\text { Skeels }\end{array}$ & Jamun & Myrtaceae & $T$ & Fruit & May-June & $350 \mathrm{~m}$ \\
\hline 33 & Tamarindus indica L. & Imali & Fabaceae & $T$ & Fruit & June-July & $350 \mathrm{~m}$ \\
\hline 34 & $\begin{array}{l}\text { Terminalia bellirica } \\
\text { (Gaertn.) Roxb. }\end{array}$ & Barro & Combretaceae & $T$ & Fruit & May-June & $350 \mathrm{~m}$ \\
\hline 35 & $\begin{array}{l}\text { Terminalia chebula } \\
\text { Retz. }\end{array}$ & Harro & Combretaceae & $T$ & Fruit & May-June & $350 \mathrm{~m}$ \\
\hline 36 & $\begin{array}{l}\text { Zanthoxylum armatum } \\
\text { Dc. }\end{array}$ & Timur & Rutaceae & $\mathrm{S} / \mathrm{T}$ & Fruit & $\begin{array}{l}\text { May- } \\
\text { October }\end{array}$ & $870 \mathrm{~m}$ \\
\hline 37 & $\begin{array}{l}\text { Zizyphus mauritiana } \\
\text { Lam }\end{array}$ & Baer & Rhamnaceae & $\mathrm{S} / \mathrm{T}$ & Fruit & $\begin{array}{l}\text { January- } \\
\text { February }\end{array}$ & $350 \mathrm{~m}$ \\
\hline
\end{tabular}

Abbreviation used in table1. GF- Growth Form; H- Herb; S- Shrub; T-Tree; WC- Woody Climber 
TABLE 2. Some of the major economically important fruits and their uses.

\begin{tabular}{|c|c|c|}
\hline Species & $\begin{array}{l}\text { Local } \\
\text { Name }\end{array}$ & Uses \\
\hline Aegle marmelos & Bel & $\begin{array}{l}\text { Ripe fleshy part of fruit is eaten. In summer season sarabat is } \\
\text { made from its edible fleshy part of fruits. } \\
\text { Medicinal uses } \\
\text { Root juice is used to cure fever. Half of a ripe fruit is eaten } \\
\text { twice a day for } 3-4 \text { days to cure constipation and dyspepsia. } \\
\text { One fourth of an unripe fruit is taken orally to cure diarrhoeaand } \\
\text { root juice is used to cure fever (Mahato \& Chaudhary, 2005). }\end{array}$ \\
\hline Artocarpus integra & Katahar & $\begin{array}{l}\text { Ripe fleshy part of fruit is eaten. Raw fruits are eaten as } \\
\text { vegetable and pickles. }\end{array}$ \\
\hline Artocarpus lakoocha & Badahar & Ripe fleshy part of fruit is eaten. \\
\hline $\begin{array}{l}\text { Choerospondias } \\
\text { axillaris }\end{array}$ & Lapsi & $\begin{array}{l}\text { Ripe fleshy part of fruit is eaten. Its fruit is used in jam, } \\
\text { pickles, candy and various kinds of sweet nuggets } \\
\text { preparation. } \\
\text { Medicinal uses } \\
\text { Ash of seeds mixed with coconut oil is used to cure wounds } \\
\text { and burns. Seeds are also used to remove cough. }\end{array}$ \\
\hline Myrica esculenta & Kaphal & $\begin{array}{l}\text { Ripe fruit is eaten with salt. } \\
\text { Medicinal uses } \\
\text { Bark decoction is used to cure diarrhoea, dysentery and chronic } \\
\text { bronchitis (Mahato \& Chaudhary, 2005). }\end{array}$ \\
\hline Phyllanthus emblica & Amla & $\begin{array}{l}\text { Its fruit is used in sweets, sauce, pickles and various kinds of } \\
\text { sweet nuggets preparation. } \\
\text { Medicinal uses } \\
\text { Powder of dried fruit (two teaspoonfuls) is given twice a } \\
\text { day for } 7 \text { days to cure diarrhoea and dysentery. About } \\
\text { two teaspoonfuls juice of fresh fruit is taken orally twice } \\
\text { a day for } 15 \text { days to cure indigestion, jaundice, anaemia } \\
\text { and heart complaint. Dried fruit is used in the preparation } \\
\text { of "Triphala"(powder of three myrobalans), an Ayurvedic } \\
\text { medicine used for liver and gastrointestinal troubles (Mahato } \\
\text { \& Chaudhary, 2005). }\end{array}$ \\
\hline Prunus persica & Aaru & $\begin{array}{l}\text { Ripe fleshy part of fruit is eaten. Its fruit is used in jam and } \\
\text { pickles preparation. }\end{array}$ \\
\hline Pyracantha crenulata & Ghangaru & $\begin{array}{l}\text { Ripe fruit is eaten. Its mature stem is used in walking stick } \\
\text { preparation and sold in market. }\end{array}$ \\
\hline Syzygium cumini & Jamun & Ripe fruit is eaten. Wood is used in furniture preparation. \\
\hline
\end{tabular}




\begin{tabular}{|c|c|c|}
\hline Tamarindus indica & Imali & $\begin{array}{l}\text { Its fruit is used in jam, pickles, sauce and various types of } \\
\text { sweet nuggets preparation. } \\
\text { Medicinal uses } \\
\text { Juice of ripen fruit is taken for } 7 \text { days for abdominal cooling } \\
\text { property and digestive effect (Mahato \& Chaudhary, 2005). }\end{array}$ \\
\hline Terminalia bellirica & Barro & $\begin{array}{l}\text { Fleshy part of fruit is eaten raw. } \\
\text { Medicinal uses } \\
\text { Two roasted fruits are chewed twice a day for } 3 \text { days to } \\
\text { improve sore throats. They are eaten three times a day } \\
\text { for a week to cure cough. It is one of the constituents of } \\
\text { "Triphala"(powder of three myrobalans)which is used in liver } \\
\text { and gastrointestinal troubles. }\end{array}$ \\
\hline Terminalia chebula & Harro & $\begin{array}{l}\text { Fleshy part of fruit is eaten raw. } \\
\text { Medicinal uses } \\
\text { Two roasted fruits are chewed twice a day for } 3 \text { days to } \\
\text { improve sore throats. They are eaten three times a day for a } \\
\text { week to cure cough. It is one of the constituents of "Triphala" } \\
\text { (powder of three myrobalans) which is used in liver and } \\
\text { gastrointestinal troubles. }\end{array}$ \\
\hline Zanthoxylumarmatum & Timur & $\begin{array}{l}\text { Fruit is eaten raw. It is mainly used as pickle and spices. } \\
\text { Medicinal uses } \\
\qquad \text { Decoction of fruit prepared in a cup of water with } \\
\text { salt is taken warm before bedtime for } 2-3 \text { days to relieve } \\
\text { abdominal pain. Powder of } 2-5 \text { fruit is taken orally twice a } \\
\text { day for } 7 \text { days with warm water to treat constipation, stomach } \\
\text { disorder and toothache (Mahato \& Chaudhary 2005). }\end{array}$ \\
\hline Zizyphusmauritiana & Baer & Matured and ripe fruit is eaten raw. \\
\hline
\end{tabular}

